\title{
RESEARCHING MEGA-EVENTS UNDER REGULATORY CAPITALISM
}

\author{
GEOFF NICHOLS,* ANGELA M. BENSON,† AND KIRSTEN HOLMES $\ddagger$ \\ *University of Sheffield Management School, Sheffield, UK \\ †School of Sport and Service Management, University of Brighton, Eastbourne, UK \\ $\ddagger$ School of Marketing, Curtin University, Perth, WA, Australia
}

\begin{abstract}
A significant legacy of the 2012 Olympic Games was to demonstrate how such an event could be delivered within the governance structure of "regulatory capitalism." The delivery of the London 2012 Games was contracted to a private company, the London Organizing Committee of the Olympic Games and Paralympic Games (LOCOG). LOCOG subcontracted packages of work, including Games research, which was conducted by a market research company as "sponsorship" in kind. Through an autoethnographic account of researching volunteers at these Games, working with the market research company, it is shown how: public accountability was reduced by the selective availability of research results; the access to research became a marketable resource; and research ethics of the private company were inconsistent with those required within a University. Therefore, the delivery of the Games through regulatory capitalism reinforced the unequal power relationships between the different event stakeholders. This leads to a discussion of implications for researching mega-events and the relationship between academic research and commercial researchers. These include the need for researchers to pay for access and to protect their intellectual property.
\end{abstract}

Key words: London 2012 Olympic Games; Olympic and Paralympic Games; Regulatory capitalism; Volunteer; Academic research

\section{Introduction}

The increasing delivery of mega-events through a governance structure of regulatory capitalism reduces public accountability and disenfranchises stakeholders outside the commercial sector, including academic researchers. This article examines these concerns through a critique of the relationship between the London Organizing Committee of the Olympic and Paralympic Games (LOCOG); a market research company, Nielsen, who were contracted to conduct all research associated with the Games; and academic researchers who worked with LOCOG and Nielsen to research the Games volunteers.

The article first describes regulatory capitalism, with relation to governance and delivery of the 2012 Games. Within this it describes LOCOG's 
relationship with Nielsen. Using autoethnographic insights it then describes in detail the process of researching volunteers at the 2012 Games and the use of research results. These are used to achieve the aims of the article and lead to a discussion of the implications for researching mega-events.

Hosting a mega-event such as the Olympic Games is an enormous financial undertaking (Preuss, 2004). The 2012 London Olympic Games officially cost $£ 11.3$ billion (Horne \& Whannell, 2012) and was the most expensive summer Olympic Games in history-surpassed only by the Sochi 2014 Winter Olympic Games (Flyvbjerg, Stewart, \& Budzier, 2016). The International Olympic Committee and Olympic Games sponsors receive attention during the Games but the vast majority of funds come from the tax payer (Tetlak, 2013). Of the funding for the 2012 Olympic Games, £9.298 billion came from public money through taxation (Tetlak, 2013) and the UK's National Lottery. Some of this funding was expended by local government and Sport England, the Government's agency for sport.

In contrast, only $£ 0.7$ billion was raised through direct sponsorship (the IOC's ongoing sponsors provided an additional $£ 0.35$ billion) and $£ 0.6$ billion from ticket sales ("London Olympics 2012," 2016). Nielsen, the market research company discussed in this paper, provided $£ 0.1$ billion in sponsorship (“London Olympics 2012,” 2016). In order to spread the cost, minimize risk from political intervention, and ensure timely delivery, the UK Government chose to deliver the 2012 London Olympic Games through regulatory capitalism. While the UK public paid for the event, the use of contracts to private companies meant that the direct benefit went to the private sector. Regulatory capitalism serves to benefit a small group of stakeholders and reinforces unequal power relationships between the different stakeholders involved in a mega-event (Spracklen \& Lamond, 2016).

\section{Regulatory Capitalism and the 2012 Games}

Although the politics of mega-events have attracted substantial attention from researchers (e.g., Brix \& Branagan, 2016; Cook \& Ward, 2011; Horne, 2017), there has been limited research on the politics surrounding the delivery of mega- events (Foley, McGillivray, \& McPherson, 2012). The London 2012 Olympic Games was the first mega-event to be delivered through regulatory capitalism and this has been put forward as one of the event's most significant legacies (Raco, 2012a). Regulatory capitalism describes a process in which the government no longer delivers services directly but facilitates the frameworks through which they are delivered by other agencies. The use of regulatory capitalism provides a key example of Gramscian hegemonic power in relation to mega-events (Gramsci, 1971). The delivery of the London 2012 Olympic Games typifies how hegemonic power was taken from the public sector and the UK taxpayer and given to commercial contractors with no accountability to the public.

The 2012 Olympic Games exemplified the process of mega-event delivery through regulatory capitalism (Raco, 2012a, 2012b, 2014) as LOCOG was a private company established to deliver the Games and was contracted to do so by the UK government. LOCOG awarded approximately 75,000 subcontracts to private companies (Girginov, 2012), including one to Nielsen, a London-based information research company, to provide research services. Similarly, the Olympic Delivery Authority (ODA), responsible for the delivery of infrastructure, spent $£ 30.7$ million between 2006 and 2009 on 112 separate consultancy contracts and "privatized the delivery process by appointing a consortium to act as delivery manager to oversee the project" (Raco, 2014, p. 186).

Although regulatory capitalism was instigated within a neo-liberalist aim of reducing state activity, it has actually led to an expansion of regulatory agencies (Braithwaite, 2008, Levi-Faur, 2005). Regulation may occur through regulatory bodies, such as quangos; for example, those regulating the energy industries. More relevant to the Olympic Games, regulation may also be through contracts between the public and private sector. Writing these contracts requires the "costly mobilization and empowerment of experts, including lawyers and consultants" (Raco, 2014, p. 179). The detailed content of contracts is critical in balancing the interests of the contractor and the state. The contractor seeks to transfer as much risk as possible to the state and to protect themselves against any change of government policy as the contract may 
cover a period far longer than the lifetime of any government. At the same time, the state aims to deliver cost-effective public services.

Raco (2012b) illustrated the importance of contract details within regulatory capitalism by recent examples. The 30-year-long private finance initiative (PFI) contracts for hospital building and management in South London have bound local Health Authority Trusts into schedules of repayment over this period. However, when Trust income has not increased at the same rate as the back-loaded repayments of the PFI contract it has had to cut costs by reducing the services offered by other hospitals in the same trust. In this way, decisions over patient welfare over a 30-year period have been constrained by the terms of the original contract. In a second example, the Franchise Agreement under which a train company provides a service in South London included clauses protecting the company from as many financial risks as possible; for example, including increases in the price of electricity or industrial action by its employees. Thus, all the risks in the contract are taken by the public sector (Raco, 2012b), which contradicts the aim of government to actually reduce their risk.

A further feature of regulatory capitalism is that the state itself has to contract experts to write the contracts, and these experts may have interests overlapping with potential contractors. Nichols and Ralston (2015) illustrated the potential overlap of interests in the awarding of contracts to deliver Olympic Games services by showing how Deloitte seconded over 130 staff to LOCOG and could thus influence the writing of contracts. At the same time Deloitte published a strategy for Olympic procurement (Deloitte Touche Tohmatsu Limited, 2011), advising companies interested in tendering for Olympic contracts. This may have been a happy coincidence for Deloitte, but clearly Deloitte would benefit from being able to advise both those writing contracts and those bidding for them. The case of Deloitte illustrated further the unequal power relations inherent in the use of regulatory capitalism as a mega-event delivery framework.

Within regulatory capitalism, confidentiality clauses covering the details of contracts-which would be normal in the private sector-may constrain public accountability. For example, although the Olympic Delivery Authority was a public company it would not reveal details of its contracts with private companies because public disclosure of these might provide a commercial advantage to the company's contractual counterparties. As Raco (2012a) put it, "it is (deemed to be) in the public interest not to know how public money is being spent” (p. 456); although subsequent freedom of information requests revealed the sums the ODA had paid contractors (Raco, 2014). Nichols and Ralston (2015) illustrated how confidentiality clauses governing LOCOG's relationships and contracts limited the production of a knowledge transfer legacy from the Games, described further below.

Thus, criticisms of regulatory capitalism are that it has a "liberty cost" because the length of contracts prevents further government intervention, and confidential details of contracts limit public accountability. Further, as Braithwaite (2008) pointed out, "markets in vice are always one step ahead of regulatory intervention” (p. 199). By this he meant that the ability of contractors to protect their interests in contracts will normally be greater than the ability of the state to protect the interest of the public. As a consequence, regulatory capitalism tends to redistribute wealth to the rich and, as the title of Braithwaite's book suggests, Regulatory Capitalism: How it Works, Ideas for Making it Work Better, might not produce the optimum outcome for society at large. However, a counter argument is that, especially in the case of the Games, it was a way of ensuring delivery of an extremely complex project was prioritized over political interventions once the Games were committed to. Our focus is to show how the relationship between academic researchers and Nielsen, the London 2012 Olympic Games official market research company, can be understood within the framework of regulatory capitalism and the consequences of this.

\section{Method}

This study uses an autoethnographic approach, as the article records the personal story of one of the coauthors (Cresswell, 2013). In an autoethnography, the authors use their own experiences to reflect on deeper issues associated with the research context (Dashper, 2016). In this case 
the article is concerned with the power relations between the private companies who were awarded the contracts for the London Olympic Games and academic researchers studying the event as well as ethical behavior more generally. The personal narrative of the researchers' experiences from working with Nielsen raises issues with broader application to how academics can conduct research at megaevents. The personal narrative-or "headnotes" (Wall, 2008) —is expanded to include e-mail and telephone correspondence with the different parties involved in this story as well as supporting documentary evidence from published articles.

This narrative involves three key parties:

1. Angela Benson and her research team Tracey Dickson, Deborah Blackman, and Anne Terwiel;

2. Nielsen, market research company, represented by David Lucas, Head of Research;

3. Amanda Alexander, a Ph.D. student at the University of Missouri and her supervisors DaeYoung Kim and Ingolf Gruen.

In addition to these three actors, other event stakeholders include the UK taxpayers who predominantly funded the Games and LOCOG, who were appointed by the UK Government to deliver the Games on their behalf.

Autoethnography is a narrative approach to research and draws on storytelling as a technique. Dashper (2016) argued that autoethnography is a relatively new method for critical event studies although this is growing (e.g., Kodama, Doherty, \& Popovic, 2013; Lamond, 2018) and has much potential to provide insights into the experiences of the different stakeholders in the events sphere. This article presents an analytic autoethnography (Coghlan, 2012), whereby the researcher is a member of the research team and their personal account is set within the wider context of the research topic. These narratives document the experiences of Benson's team as they sought to conduct research at the London 2012 Olympic Games. However, as noted above, this narrative involves two other parties who are inextricably linked with the story. Both parties were contacted as part of this study but did not respond to our requests for clarification.
Researching the 2012 London

Olympic and Paralympic Games

London was the first host city of the Olympic and Paralympic Games to have an official market research provider. In June 2009, LOCOG appointed Nielsen, a major market research organization, as a "value in kind" sponsor; as such, Nielsen was expected to contribute between $£ 10-£ 20$ million worth of services. For example, the chief executive of LOCOG was reported as saying that Nielsen researched the price elasticity of demand for tickets to determine ticket pricing acceptable to the public. Nielsen also researched the propensity of the UK public to volunteer, to help define the required number of volunteers and how to market this opportunity to prospective volunteers (Fernandez, 2012). Up to July 2012, Nielsen conducted over 80 such research projects for LOCOG.

Whether intended or not, the effect of contracting research to Nielsen was that the ability of academics to research the London 2012 Games was limited. The use of "nondisclosure" agreements, common within commercial contracting, had already prevented a publicly-funded Knowledge Transfer project into the Games achieving its potential. This project paired 10 academics with managers of functional areas of LOCOG to conduct research from autumn 2011, with the aim of producing a report (Girginov \& Gold, 2013). However, only three of the researchers associated with the project were able to contribute to the report due to difficulties they encountered with gaining access to official information. These included the requirement for researchers to sign a "nondisclosure agreement," which implied that they could not publish material regarding the London 2102 Games, using information gained from LOCOG, without LOCOG's permission (Nichols \& Ralston, 2015). The use of nondisclosure agreements in this context casts a veil over attempted analyses of the event and its delivery as well as evaluating its outcomes.

We presume that this nondisclosure agreement was a blanket “agreement” signed by all LOCOG's contractors and official sponsors. This ensured commercial confidentiality, but it also gave LOCOG complete control over information about the London 2012 Games, which was important from their perspective in terms of promoting positive public 
perceptions. In relation to this article, this prevented at least one academic researcher working with the volunteer manager at LOCOG because the use of information from the collaboration was potentially restricted, which limited the value of an academic analysis. As described below, official access to researching volunteers at 2012 was restricted to academics working with Nielsen. Other academics have researched volunteering at the Games, but have been restricted to using small, independently recruited samples (e.g., Holmes, Nichols, \& Ralston, 2017).

\section{Surveying the London 2012 Olympic and Paralympic Games: Gaining Access and Planning Research}

Gaining access to research at mega-events is often complex due to the many layers of approval that are needed and often competing groups of researchers who are seeking access to different elements of the event. Although research access for academics at the London 2012 Games was difficult, an independent research team (Tracey Dickson, Angela Benson, Deborah Blackman, and Anne Terwiel) submitted an application to the International Paralympic Committee (IPC) to request approval to replicate at the London 2012 Games a survey of volunteers that they had used previously at the Vancouver 2010 Winter Olympics. This had examined the profile, motivation, and satisfaction of volunteers and the legacy of volunteering after the 2010 Games. The 2010 Vancouver Games research study was supported by the IPC and the Vancouver Winter Olympics Committee (VANOC), and results (including details of the survey instrument) were published in a number of papers (Benson, Dickson, Terwiel, \& Blackman, 2014; Dickson, Benson, Blackman, \& Terweil; 2013; Dickson, Benson, \& Terwiel, 2014).

Permission to undertake the London 2012 Games research was granted in August 2011 by the IPC, who agreed to speak to LOCOG in order for the research team to negotiate access to undertake the research. The research team met in London in October 2011. Dickson and Benson were able to secure a meeting with a member of the LOCOG staff, which opened up a dialogue with LOCOG regarding the potential to undertake the research.
A meeting took place in March 2012 between Benson, the Head of Volunteer Program, the Head of Research \& Insight (LOCOG—Nielson), a member of the Meta Evaluation team, a representative from the National Council for Voluntary Organizations (NCVO), a government representative from the Department for Culture, Media \& Sport (DCMS), and the original contact from LOCOG. Further e-mail exchanges led to a meeting in May 2012. These e-mails from Benson to the members at the March meeting included a pdf document of the proposed questionnaire, which was based on the Vancouver 2010 survey. This meeting established the basis for an agreement that LOCOG/Nielson would send out the questionnaire, subject to a number of changes in question wording to the original survey, which is common with studies across multiple events (Lockstone-Binney, Holmes, Baum, \& Smith, 2014). Further e-mails were then exchanged between those involved in previous meetings and the research team to finalize the questionnaire to meet everyone's approval. It took 5 months for the final questionnaire to be agreed, which was an adaption of the questionnaire used in Vancouver 2010.

On September 11, 2012, following the completion of both the Olympic and Paralympic events, Nielsen distributed the questionnaire by e-mail to all those who had volunteered at the London Games (“Games Makers"). The UK Government consistently claimed that "the London 2012 volunteer programme . . . recruited and trained 70,000 people to support the staging of the Games" (DCMS, 2013, p. 3). The Head of Research \& Insight confirmed that "Yes, the questionnaire will be going out to the full Games Maker database” (September $11,2012)$ so the research team assumed the sample was 70,000 volunteers.

For Benson and Dickson, distribution would ideally have been 1 month prior to the start of the Games to make timing comparable with the Vancouver study. However, "a requirement of LOCOG was that the survey was to be sent out two days after the completion of the Paralympics [and] the survey was closed 5 days later" (Dickson et al., 2014, p. 167).

We acknowledge that academia is a competitive field and the research team was keen to ensure exclusive use of this data set, and requests for a 
formal document stating this were expressed during the discussions. Indeed, the questionnaire instrument represented their intellectual property. The team was verbally assured that their questionnaire was being used and the data would be forwarded to them once it was collected. This promise was later confirmed by the Head of Research \& Insight in e-mail exchanges with DCMS staff and again by David Lucas, the Head of Research at Nielsen, stating that the raw data would only go to two researchers (Dickson and Benson) and not be shared with any other party.

In response to the DCMS asking the research team for use of some of the data, Dickson replied:

As David (Lucas) has said, in general this was being run for us as part of an IPC approved research project, but we agreed with LOCOG that they would do a "top line" analysis of the data, which I believe Anita [member of the Meta Evaluation team commissioned by the DCMS] is working on, as part of the post Games reporting. (E-mail extract September 28, 2012)

As a result of further discussions between DCMS and the research team, it was agreed that Dickson and Benson would write an annex document for the DCMS Meta Evaluation Report, which was the Government's official review of a Games legacy (Dickson \& Benson, 2013). It was on this basis that Benson's team believed that they would have unique access to the data.

Surveying the London 2012 Olympic and Paralympic Volunteers:

Access to the Survey Results

In spite of Nielsen's assurances that Benson's team would receive exclusive access to the survey results, there appear to be conflicting understandings of who would be given access to these data. This, and conflicting claims for design of the survey, also illustrate ethical questions, which appear to originate from the involvement of a commercial research partner, which has signed a nondisclosure agreement.

Although Dickson and Benson believed they would be given exclusive access to the survey results these were also passed to Alexander and used as the basis of a Ph.D. submitted at the University of Missouri (Alexander, 2013), and subsequently in an academic article (Alexander, Kim, \& Kim, 2015).
Dickson and Benson were sent results by Nielsen on September 18, 2012. The 11,451 respondents provided the largest data set yet produced of Olympic and Paralympic volunteers. An article reporting analysis of motivations, compared with the motivations of volunteers at Vancouver, 2010, was submitted in July 2013 and published in 2014 (Dickson et al., 2014). This article reported that:

The instrument used for both Vancouver 2010 (see Dickson et al., 2013) and London 2012 was developed from previous uses of the SEVMS [Special Events Volunteer Motivation Scale]. . . . The final instrument design for London 2012 was developed in conjunction with LOCOG's Research Department to support their evaluation strategies and to build upon previous research on large and mega sport volunteers.

However, the same survey results were used in Alexander's Ph.D. thesis, “A model of volunteer intention at a mega-event, the London 2012 Olympics," submitted in May 2013, at the University of Missouri (Alexander, 2013). This used a sampling frame of 44,700 Olympic volunteers. Of these, 11,521 responded, a response rate of $25.5 \%$ (Alexander, 2013, p. 65). A subsequent paper based on this thesis, of which one of the supervisors was a co-author (Alexander et al., 2015), used a sample of 11,451; having removed outliers and incomplete responses. This $(11,451)$ was identical to the size of the sample sent to Dickson and Benson.

Alexander's thesis stated that she obtained the survey data though direct contact with David Lucas, Head of Research \& Insight at Nielsen: "Data was directly obtained from Nielson (London 2012 Volunteer Evaluation, 2012; https://sdel.acnielsen. co.uk)" (Alexander, 2013, p. 68). The internet link in this section is no longer valid, but earlier in the thesis Alexander quotes a personal communication with the manager of Nielsen: "without these individuals we wouldn't know the Olympics as we know it today" (Alexander, 2013, p. 55), thus confirming her direct contact with David Lucas.

Thus, Dickson and Benson thought they had been assured by David Lucas that they would have unique access to the volunteer survey results, but these were also passed to Alexander. This raises ethical questions over the behavior of Nielsen.

To further unpick how two independent groups of researchers reported very similar datasets, 
we examine the methods from Alexander's thesis. In the thesis the methods are described:

An online questionnaire was used to collect data for this study. The sample frame consisted of individuals that were volunteers of the London 2012 Olympics. In an attempt to reach all volunteers to adequately provide a profile of Olympic volunteers, all individuals that provided an e-mail address along with consent to receive communication from the London Organising Committee of the Olympic Games and Paralympic Games received an e-mail invitation to become a participant of the research study. (Alexander, 2013, p. 56)

On sampling, the thesis reports that:

The sample was obtained through collaborative efforts with the London Organising Committee of the Olympic Games and Paralympic Games, direct contact with the sample was not possible due to regulations and policies set forth by the United Kingdom that prohibited the direct release of volunteers' contact information. (Alexander, 2013, p. 57)

And on questionnaire development, Alexander's (2013) thesis reports that:

A self-administered online questionnaire was developed through the collaborative efforts of the researcher and the London Organising Committee of the Olympic Games and Paralympic Games.... The purpose of research overlapped for both the researcher and Head of Research and Insight for the London Organising Committee of the Olympic Games and Paralympic Games. (p. 59)

In her 2015 article, Alexander reports that, “The questionnaire survey items for the present research were developed through collaborative efforts between the researchers and a contact within the Head of Research and Insight for . . LOCOG" (p. 3).

The questionnaire reproduced in Alexander's (2013) Ph.D. (pp. 141-154) is identical to that sent by a member of the LOCOG staff working with Nielson on the London 2012 Meta Evaluation to Dickson, Benson, and David Lucas, on September 17, 2012. The research team recorded the trail of e-mails from May 11, 2012 to September 17, 2012, tracking the changes to the questionnaire that were negotiated between Dickson and Benson and
Nielson, with LOCOG and DCMS staff, during that time. As noted above, the design was developed from the version used by the Dickson and Benson's research team in Vancouver 2010.

The authors contacted Lucas, Alexander, and Dae-Young Kim (Kim was Alexander's supervisor, coauthor of her article, and a member of the ethics team approving her research) to clarify the relationship between Alexander and Nielsen. In response to an inquiry from Dickson and Benson, David Lucas said that the Nielsen team would only ever have supplied her [Alexander] with the data relating to the questions that were run for her, though could not vouch for whether or not the Volunteering team shared other information with her. By "the Volunteering team” David Lucas must mean LOCOG's volunteer management staff.

An e-mail from one of the authors of this article to Dae-Young Kim asked for clarification on his role in the design of the volunteer survey. DaeYoung Kim responded that he had codeveloped the questionnaire with Nielsen and that Alexander's survey was designed by her with the supervisory team and then modified by Nielsen. Clarification was also sought from Alexander, but with no response. In contrast, Dickson and Benson have provided a detailed account of their survey design and administration through the autoethnographic account presented in this article and in other published articles (Benson et al., 2015; Dickson et al., 2013).

Dae-Young Kim was also asked if he had paid Nielson for any data. This was queried because when Dickson and Benson asked Nielsen if they could repeat their survey again at the 2016 Rio de Janeiro Olympic Games, where Nielsen had also been appointed the official researchers, Nielsen indicated that this would probably not be possible without a fee (suggested to be in the region of $£ 10,000)$. Dae-Young Kim said he had not paid for any results.

The lack of information and conflicting views raises the possibility that Nielsen worked with two sets of academics. Possibly Dickson and Benson's group provided the initial questionnaire, which was then modified through consultations with Alexander and Kim, before the final version was sent to Dickson and Benson by LOCOG on September 17, 2012. However, this does not alter the fact 
that Dickson and Benson were assured by Nielsen they would have exclusive use of the results; and the questionnaire Alexander claims to have had a major role in designing was originally designed by the Dickson and Benson group.

\section{Surveying the London 2012 Olympic and Paralympic Volunteers: Selective use of the Survey Results}

The ethical issues raised in the account presented in this article stem from the use of regulatory capitalism to deliver the London 2012 Olympic Games. This created different power dynamics between a nonaccountable private market research company and academic researchers who are accountable to their university ethics committees and academic peers when seeking to publish their work. The data provided to the two research groups suggests that Nielsen (and possibly LOCOG) sought to release selective data about the volunteer program to ensure a positive image was publicly presented. The selective release of survey results by the commercial researcher illustrates a possible conflict with public accountability.

Both groups of researchers were provided with different information about the sample. Alexander reports that 44,700 questionnaires were sent out "through collaboration with the London 2012 Olympic volunteer teams” (Alexander et al., 2015, p. 3). Dickson and Benson were not made specifically aware of the sampling frame and had to assume it was "the estimated 70,000 volunteers"the total number of volunteers consistently cited by LOCOG. As all Games Maker communication was conducted via e-mail, Alexander's reported sampling frame of 44,700 may be an accurate representation of the total number of volunteers, and suggests that 70,000 was an exaggeration on the part of LOCOG.

Alexander's account in her thesis, cited above, that "one questionnaire was developed as a means to ensure that potential participants of the study would not opt to participate in both questionnaires and as a result lower the response rate of either research entity" (p. 59), supports evidence that the figure of 70,000 double counted those volunteering in the Games and Paralympic Games. However, for the UK Government maintaining the higher figure as a political aspect of a "legacy" was important (Nichols, 2017).

An aspect of the sample that was sensitive to the UK government, and available to both research teams, was the demographics of the sample. Alexander reported the break-down of her sample of 11,451 by ethnicity, area of the UK, and by three income brackets. For example, she reports that over 35.5\% of those who indicated their household income earned over $£ 50,000$ and $80 \%$ over $£ 22,000$. The UK median household income was $£ 14,000$ at this time, so Games Makers were clearly unrepresentative in this respect. This is information LOCOG have not elsewhere made public, possibly because it contradicts LOCOG's claims that their volunteering was socially inclusive (DCMS, 2013).

Alexander also reports that $70.6 \%$ of her sample came from London and the South East, while the DCMS reported 55\% came from these areas (DCMS, 2013). If Alexander's reporting was correct then either the survey sample significantly overrepresented volunteers from these areas, or Games Makers were less representative of the UK population than the DCMS claimed. In considering the number of volunteers at the Games it is possible that the same people volunteering at both the Olympic and Paralympic Games were double counted, as has happened at previous Olympic Games (Lockstone-Binney, Holmes, Shipway, \& Smith, 2016). In considering the demographics of volunteers, Dickson and Benson had access to this data set, although they choose not to report on it in the DCMS annex (DCMS, 2013).

Thus, it is only via the results reported by Alexander that we have become aware that the total number of volunteers may have been closer to 44,770 than the 70,000 officially claimed at the London Games.

Discussion and Conclusions: Regulatory Capitalism and Researching the Olympic Games

This article has examined regulatory capitalism, in which work formerly done by the public sector is contracted to the private sector, and the outcome is contingent on details of the contract (Braithwaite, 2008) and how it has affected public accountability and the relationship between academics and mega-events.

As with other mega-events, the primary sponsor of the London 2012 Olympic Games was the 
UK taxpayer (Flyvbjerg et al. 2016; Tetlak, 2013). However, public accountability for the considerable sums spent on the Games was reduced because research by Nielsen was mainly used just for LOCOG, and results of the volunteer survey were released selectively. Specifically, if our proposition that the Games involved substantially fewer than 70,000 volunteers is correct, this information would have undermined official claims. Confidentially clauses, common in commercial contracts, limited critical analysis of the Games as researchers were both unable to gain access and publish their findings without possible censure (Girginov \& Gold, 2013). This also brings into question the extent to which other research conducted by Nielsen for LOCOG may have been withheld because its results did not support the public impression LOCOG wished to give. Given that the London 2012 Olympic Games were primarily publicly funded (Tetlak, 2013), the public might want to see the results of Nielsen's 80 projects that informed this event.

Under the framework of regulatory capitalism, research findings, and the access to research, become a marketable resource. Nielsen's relationship with LOCOG enabled them to also be appointed the official researchers of the 2016 Rio de Janeiro Olympic Games. As a key broker they attempted to use this position to sell access to volunteers at Rio 2016.

Although not a main concern of this article, LOCOG's commercial priorities also meant that the database of $5.3 \mathrm{~m}$ individuals, including both volunteers and people who bought a ticket for the Olympics, was sold in February 2013, through a competitive tendering process, to a partnership of Sport England, UK Sport, and London \& Partners. London \& Partners are a public-private partnership that aims to increase leisure and business visitors and bids to secure major events in London. This prevented use of the database earlier by Sport England to try and recruit sports volunteers from those at the Games (Nichols \& Ralston, 2015). The failure of OCOGs including LOCOG to manage access to the volunteer database after the Games has been noted as a significant limitation in creating a volunteer legacy (Lockstone-Binney et al., 2016). This is yet another example of how regulatory capitalism in the delivery of the London 2012 Olympic Games reinforced hegemonic power and reduced the potential benefits of the event to the public (Gramsci, 1971).

The research ethics of Nielsen, in promising access to results to one set of researchers and then passing the results to another set, are questionable. Nielsen could have been held accountable for this if their relationship with the research team had been enshrined in a formal contract. In terms of the relationship between Nielsen and both teams of academic researchers, there was clearly a lack of transparency and an apparent lack of concern for either team's intellectual property. The conflict of commercial and research interests means it is important for Dickson and Benson to copyright their questionnaire to prevent Nielsen using it again without their permission and it is not clear whether this is still possible. In contrast legal protections were enshrined in contracts awarded to official sponsors of the Games (James \& Osborn, 2012) and enforced vigorously.

We do not know what the volunteer Games Makers who responded to the questionnaire were told was the purpose of the research and how results would be used or who would have access to the raw data. Any university ethics committee would have required the purpose of the research to have been clearly stated; whether it was for LOCOG, Dickson and Benson's research, or Alexander's Ph.D. Alexander's position is problematic as she states that she designed the survey Dickson and Benson were mainly responsible for. This extends to the statements in the article by Alexander et al. (2015), and the role of D-Y Kim in giving ethical approval of Alexander's thesis. However, without responses from these actors in this story-although requested-it is not possible to unpack exactly what happened.

An implication of the delivery of mega-events through the structures of regulatory capitalism is that academic researchers are advised to copyright their research tools and obtain formal contracts with the event managers; specifying access to, and use of, research results. Contracts will need to be negotiated by their university research office. Reliance on trust, verbal, or written agreements is unlikely to be sufficient to protect intellectual property as there is a potential conflict between interests of commercial companies and academics (Nichols \& Ralston, 2015), with commercial 
companies prioritizing theirs (Braithwaite, 2008). Further, access to research becomes commercial property. Academic researchers may have to pay substantial sums to obtain data, even using their own instruments.

Another implication for the relationship between academic research and mega-sports events is the loss of coordination. Clearly in this case, Benson and Dickson could not coordinate with Alexander or any other researchers seeking to collect data from the Games Makers. From an academic perspective, collection of survey data could have been complemented by qualitative work. Nielsen claims to have done this in the "over 80 research projects for LOCOG," including research on attitudes to volunteering and price sensitivity (Fernandez, 2012). However, again these data are not publicly available. There were qualitative studies of volunteers at the 2012 Olympic Games, but these were unofficial and completely uncoordinated with the questionnaire survey. Examples include: Nichols and Ralston (2016); Holmes et al. (2017); Koutrou and Pappous (2016). These had to rely on selfgenerated samples, often via snowballing from personal contacts.

There are also implications for governments in using regulatory capitalism to deliver mega-events. Much is written about the importance of building a legacy from the Olympic Games (Doherty, 2009; Koutrou \& Pappous, 2016) and the London Games were not different in proposing a volunteer legacy from the event (DCMS, 2012). However, the commercial sale of the public data in the volunteer database has prevented public organizations, including Sport England, from making full use of these data in legacy planning and implementation. The use of nondisclosure agreements may have led to a more positive reporting of the event in the media but it has also limited knowledge transfer between this event and other Olympic Games (Girginov \& Gold, 2013). Rather, the knowledge remains the property of commercial organizations who can use this to their advantage in selling their services to future mega-events, as was the case with Nielsen at the Rio de Janeiro 2016 Olympic Games.

Overall, loss of public accountability and control over research may be a "liberty cost" of delivering a "successful" Olympic Games through regulatory capitalism (Raco, 2012a). Regulatory capitalism has been shown to be an effective way to ensure an extremely complex mega-event, with considerable political capital invested in it, is delivered on time (Raco, 2014). So, we are likely to see this governance structure repeated with future events hosted by neoliberal democracies. Thus, the implications for conducting academic research as discussed above will be significant.

\section{References}

Alexander, A. (2013). A model of volunteer intention at a mega-event, the London 2012 Olympics. Unpublished Ph.D. Thesis, University of Missouri-Columbia, Columbia, MO.

Alexander, A., Kim, S-B., \& Kim, D-Y. (2015). Segmenting volunteers by motivation in the 2012 London Olympic Games. Tourism Management, 47, 1-10.

Benson, A., Dickson, T., Terwiel, A., \& Blackman, D. (2014). Training of Vancouver 2010 volunteers: A legacy opportunity? Journal of the Academy of Social Sciences, 9(2), 210-226.

Braithwaite, J. (2008). Regulatory capitalism: How it works, ideas for making it work better. Cheltenham, UK: Edward Elgar.

Brix, J., \& Branagan, P. (2016). Of mechanisms and myths: Conceptualising states' "soft power" strategies through sports mega-events. Diplomacy and Statecraft, 27(2), 251-272.

Coghlan, A. (2012). An autoethnographic account of a cycling charity challenge event: Exploring manifest and latent aspects of the experience. Journal of Sport \& Tourism, 17(2), 105-124.

Cook, I., \& Ward, K. (2011). Trans-urban networks of learning, mega events and policy tourism: The case of Manchester's Commonwealth and Olympic Games projects. Urban Studies, 48(12), 2519-2535.

Cresswell, J. (2013). Qualitative inquiry and research design: Choosing among five approaches. Thousand Oaks, CA: Sage.

Dashper, K. (2016). Researching from the inside: Autoethnography and critical event studies. In I. Lamond \& L. Platt (Eds.), Critical event studies: Approaches to research (pp. 213-229). London, UK: Palgrave Macmillan.

Department for Culture, Media \& Sport. (2012). Beyond 2012: The London 2012 legacy story. London, UK: Author.

Department for Culture, Media \& Sport. (2013). London 2012 meta-evaluation: Community engagement evidence base. London, UK: Author. Available from https://www. gov.uk/government/uploads/system/uploads/attachment_data/file/224146/Report_5_Community_Engagement_Evidence_Base_FINAL.pdf

Deloitte Touché Tohmatsu Limited. (2011). The state of play: London 2012-Ready or not? (Special Edition). London, UK: Author. 
Dickson, T., \& Benson, A. (2013). London 2012 Games Makers: Towards redefining legacy. In Policy: Creating a lasting legacy from the 2012 Olympic and Paralympic Games. Series: Meta-evaluation of the impacts and legacy of the London 2012 Olympic Games and Paralympic Games. London, UK: Department for Culture, Media \& Sport.

Dickson, T., Benson, A., Blackman, D., \& Terwiel, A. (2013). “It's all about the Games!” 2010 Vancouver Olympic and Paralympic Winter Games volunteers. Event Management: An International Journal, 17, 77-92.

Dickson, T., Benson, A., \& Terwiel, A. (2014). Mega-event volunteers, similar or different? Vancouver 2010 vs London 2012. International Journal of Event and Festival Management, 5, 164-179.

Doherty, A. (2009). The volunteer legacy of a major sport event. Journal of Policy Research in Tourism, Leisure and Events, 1(3), 185-207.

Fernandez, J. (2012, July 27). Making Olympic history. Research Live. Retrieved from https://www.researchlive.com/article/features/making-olympic-history/id/ 4007800

Foley, M., McGillivray, D., \& McPherson, G. (2012). Event policy: From theory to strategy. Abingdon, UK: Routledge.

Flyvbjerg, B., Stewart, A., \& Budzier, A. (2016). The Oxford Olympic study 2016: Cost and cost-overrun at the Games. Said Business School Working Papers. Oxford, UK: Said Business School, University of Oxford.

Girginov, V. (2012). Governance of the London 2012 Olympic and Paralympic Games. In V. Girginov (Ed.), The handbook of the London 2012 Olympic and Paralympic Games, volume one: Making the Games (pp. 130-144). Abingdon, UK: Routledge.

Girginov, V., \& Gold, J. (2013). London 2012 Olympic and Paralympic Games knowledge transfer. London, UK: Podium.

Gramsci, A. (1971). Selections from the prison notebooks. New York, NY: International Publishers.

Holmes, K., Nichols, G., \& Ralston, R. (2017). "It’s a oncein-a-lifetime experience and opportunity-deal with it!” Volunteer perceptions of the management of the volunteer experience at the London 2012 Olympic Games. Event Management, 22(3), 389-403.

Horne, J. (2017). Sports mega-events- three sites of contemporary political contestation. Sport in Society, 20(3), 328-340.

Horne, J., \& Whannell, G. (2012). Understanding the Olympics. Oxford, UK: Routledge.

James, M., \& Osborn, G. (2012). The Olympic laws and the contradictions of promoting and preserving the Olympic ideal. In V. Girginov (Ed.), The handbook of the London 2012 Olympic and Paralympic Games, Volume one: Making the Games (pp. 74-86). Abingdon, UK: Routledge.

Kodama, E., Doherty, A., \& Popovic, M. (2013). Front line insight: An autoethnography of the Vancouver 2010 volunteer experience. European Sport Management Quarterly, 13(1), 76-93.

Koutrou, N., \& Pappous, A. (2016). Towards an Olympic volunteering legacy: Motivating volunteers to serve and remain-A case study of London 2012 Olympic Games Volunteers. Voluntary Sector Review, 7(3), 269-291.

Lamond, I. (2018). The challenge of articulating human rights at an LGBT "mega-event": A personal reflection on Sao Paulo Pride 2017. Leisure Studies, 37(1), 36-48.

Levi-Faur, D. (2005). The global diffusion of regulatory capitalism. Annals of the American Academy of Political and Social Science, 598, 12-32.

Lockstone-Binney, L., Holmes, K., Baum, T., \& Smith, K. (2014). Event volunteering evaluation (EVE) project: Challenging the methodological limits of event volunteering research. In K. Smith, L. Lockstone-Binney, K. Holmes, \& T. Baum. (Eds.), Event volunteering: International perspectives on the event volunteering experience (pp. 167-181). London, UK: Routledge.

Lockstone-Binney, L., Holmes, K., Shipway, R., \& Smith, K. A. (2016). Evaluating the volunteering infrastructure legacy of the Olympic Games: Sydney 2000 and London 2012. Lausanne, Switzerland: IOC.

London Olympics 2012: Where does they money come from-and where it's being spent. (2016). The Guardian. Retrieved from https://www.theguardian.com/sport/ datablog/2012/jul/26/london-2012-olympics-money

Nichols, G. (2017). Volunteers in community sports associations: A literature review. Leiden, Netherlands: Brill. (Originally published as Voluntaristics Review, 2(1) 2017)

Nichols, G., \& Ralston, R. (2015). The legacy costs of delivering the 2012 Olympic and Paralympic Games through regulatory capitalism. Leisure Studies, 34, 389-404.

Nichols, G., \& Ralston, R. (2016). Talking 'bout my generation: Generational differences in the attitudes of volunteers at the 2012 Olympic Games. Voluntary Sector Review, 7(2) 127-148.

Preuss, H. (2004). The economics of staging the Olympic Games: A comparison of the Games 1972-2008. Cheltenham, UK: Edward Elgar.

Raco, M. (2012a). The privatisation of urban development and the London Olympics 2012. City, 16, 452-460.

Raco, M. (2012b). The new contractualism, the privatisation of the welfare state, and the barriers to open source planning. Planning, Practice and Research, 28(1), 45-64.

Raco, M. (2014). Delivering flagship projects in an era of regulatory capitalism. International Journal of Urban and Regional Research, 38(1), 176-197.

Spracklen, K., \& Lamond, I. (2016). Critical event studies. Abingdon, UK: Routledge.

Tetlak, K. (2013). The taxpayer as the unofficial sponsor of the London 2012 Olympic Games. International Sports Law Journal, 13, 97-103.

Wall, S. (2008). Easier said than done: Writing an autoethnography. International Journal of Qualitative Methods, 7(1), 38-53. 